\title{
Yesterday I Died
}

\author{
Yenkuei Chuang ${ }^{1}$ (iD
}

Accepted: 26 February 2021 / Published online: 11 March 2021

(C) The Author(s), under exclusive licence to Springer Science+Business Media, LLC, part of Springer Nature 2021

Yesterday I died. A mini death. A sudden sharp snap of my heartstrings when I heard that my children were not going back to school for the rest of the year. Their school had shut down with COVID-19 still out infecting and harming. When I heard this, my breath suddenly stopped. I stood still. Paralyzed. I couldn't move because it was not the life I knew.

Then I thought of my parents. Eighty-five and ninety years old, stroke and cancer survivors, and living alone in their house 2600 miles away in California. Images of them being spit on and called racial slurs appeared in my mind. No, their white neighbors would protect them from that. Would they? Or would they blame this pandemic on them because their President called it a Chinese virus? Worse, what if my parents caught the virus?

That was yesterday. My mind snapped and went wild with fears.

I died because it was not the life I knew. But it was good that $I$ died. That I was not in touch with reality and that I didn't even know that it did not know.

Impermanence is central to the teachings of Buddhism. All phenomena in life is characterized by change. No one is exempt from sickness, aging, death, and loss. This is common sense, and you don't need to be a Buddhist to know the truth of impermanence.

Yet, to live this truth-knowing that change is happening every moment - is the hardest thing that I've ever had to do. Every cell in my body resists this. I don't like knowing that I will grow old and die. I'm surprised and annoyed when I see my hair graying and thinning, and my skin flabbier and wrinkled. I still like to see myself forever twenty-nine.

With COVID-19 disrupting every norm I knew, my mind jumped into action like a superhero to ward off fears of uncertainty and change. Without any conscious effort, I immediately thought: "Okay, a couple of months of this? I can deal."

Yenkuei Chuang

info@yenkuei.org

1 Boston Center for Contemplative Practice, 19 Terrace Avenue, Newton Highlands, MA 02461, USA
When the $I$ that died yesterday, however, it was a rude awakening. I didn't know that I had been living with the idea that this pandemic would last only a couple of months. When the news came that it would be otherwise, it felt as if life got sucked out of me. A sudden cessation of breath, thoughts, and forward momentum. All that I had been thinking and planning went poof! Gone. Empty.

For a moment, it felt oddly peaceful as if I were in deep meditation - this mind and heart at rest without a concern. A momentary experience of nothingness. And then, it started up again.

Will my kids be okay? Will my parents be okay? This isn't fair. My daughter had just transferred to this school. She will miss the prom and getting to make new friends. It just isn't fair. We can't cancel another flight to California. I am so annoyed. I am so angry. I could scream out in rage.

But wait. Who is this $I$ that's popping out now? What is this $I$-no longer at rest but burning with anger?

I see that it is another superhero $I$ rising up to resist COVID-19 and protect me from feeling vulnerable and afraid. I am impressed by the power of this facile mind that is quick to strategize and defend against any kind of threat. This time, however, awareness is present to notice the arising and passing of I's moment to moment. Know that this is natural just like birth and death. Happens all the time, not just COVID-19.

This time, however, can I remember that they are insubstantial and impermanent like the rain drops? Can I live with Right View as the Buddha had taught — seeing the inconstant as inconstant, the stressful as stressful, and what's not self as not self?

Can I welcome this knowing with each breath? In and out. Coming and going. Just like that. Welcome everything, even the unwelcome. Meet the fear and the rage. Greet them all and grieve.

Because we love, and we care. And because, it doesn't last. And because, it's real.

Publisher's Note Springer Nature remains neutral with regard to jurisdictional claims in published maps and institutional affiliations. 